Braz J Med Biol Res, January 2012, Volume 45(1) 43-48

doi: 10.1590/S0100-879X2011007500154

Sertraline inhibits formalin-induced nociception and cardiovascular responses

C.H. Santuzzi, H.A. Futuro Neto, J.G.P. Pires, W.L.S. Gonçalves, R.V. Tiradentes, S.A. Gouvea and G.R. Abreu

The Brazilian Journal of Medical and Biological Research is partially financed by

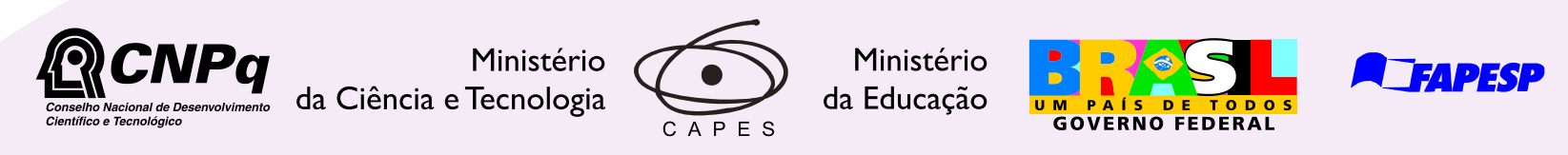
Institutional Sponsors
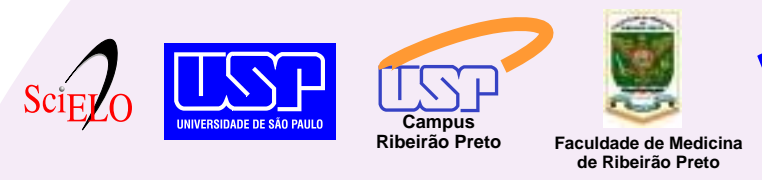

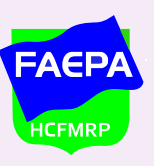

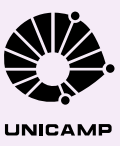

SHIMADZU

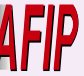

Associaçăo
Fundo
de Incentivo

Explore High - Performance MS Orbitrap Technology analitica Thermo 


\title{
Sertraline inhibits formalin-induced nociception and cardiovascular responses
}

\author{
C.H. Santuzzi ${ }^{1}$, H.A. Futuro Neto $2,3,4$, J.G.P. Pires ${ }^{3,5}$, W.L.S. Gonçalves ${ }^{5}$, \\ R.V. Tiradentes ${ }^{1}$, S.A. Gouvea ${ }^{1}$ and G.R. Abreu ${ }^{1}$ \\ ${ }^{1}$ Departamento de Ciências Fisiológicas, ${ }^{2}$ Departamento de Morfologia, Centro de Ciências da Saúde, \\ Universidade Federal do Espírito Santo, Vitória, ES, Brasil \\ ${ }^{3}$ Escola de Medicina da Empresa Brasileira de Ensino, Pesquisa e Extensão, Vitória, ES, Brasil \\ ${ }^{4}$ Escola Superior de Ciências da Saúde, Santa Casa de Misericórdia de Vitória, Vitória, ES, Brasil \\ ${ }^{5}$ Centro Universitário do Espírito Santo, Colatina, ES, Brasil
}

\begin{abstract}
The objective of the present study was to determine the antihyperalgesic effect of sertraline, measured indirectly by the changes of sciatic afferent nerve activity, and its effects on cardiorespiratory parameters, using the model of formalin-induced inflammatory nociception in anesthetized rats. Serum serotonin (5-HT) levels were measured in order to test their correlation with the analgesic effect. Male Wistar rats $(250-300 \mathrm{~g})$ were divided into 4 groups ( $=8$ per group): sertraline-treated group (Sert + Saline (Sal) and Sert + Formalin (Form); $3 \mathrm{mg} \cdot \mathrm{kg}^{-1} \cdot \mathrm{day}^{-1}$, ip, for 7 days) and saline-treated group (Sal + Sal and Sal + Form). The rats were injected with $5 \%(50 \mu \mathrm{L})$ formalin or saline into the right hind paw. Sciatic nerve activity was recorded using a silver electrode connected to a NeuroLog apparatus, and cardiopulmonary parameters (mean arterial pressure, heart rate and respiratory frequency), assessed after arterial cannulation and tracheotomy, were monitored using a Data Acquisition System. Blood samples were collected from the animals and serum 5-HT levels were determined by ELISA. Formalin injection induced the following changes: sciatic afferent nerve activity $(+50.8 \pm 14.7 \%)$, mean arterial pressure $(+1.4 \pm 3 \mathrm{mmHg})$, heart rate $(+13 \pm 6.8 \mathrm{bpm})$, respiratory frequency $(+4.6 \pm 5 \mathrm{cpm})$ and serum $5-\mathrm{HT}$ increased to $1162 \pm 124.6 \mathrm{ng} / \mathrm{mL}$. Treatment with sertraline significantly reduced all these parameters (respectively: $+19.8 \pm 6.9 \%,-3.3 \pm 2 \mathrm{mmHg},-13.1 \pm 10.8 \mathrm{bpm},-9.8 \pm 5.7$ $\mathrm{cpm})$ and serum $5-\mathrm{HT}$ level dropped to $634 \pm 69 \mathrm{ng} / \mathrm{mL}(\mathrm{P}<0.05)$. These results suggest that sertraline plays an analgesic role in formalin-induced nociception probably through a serotonergic mechanism.
\end{abstract}

Key words: Sertraline; Formalin-induced pain; Antinociceptive effect; Cardiovascular system; Sciatic nerve activity

\section{Introduction}

Several studies in rodents have suggested that serotonin (5-HT) modulates nociceptive responses (1-3). However, its involvement in pain processing is complex since 5-HT may inhibit and/or facilitate nociceptive transmission depending on the type of nociceptive stimuli and the nature of the 5-HT receptors expressed, i.e., peripheral and/or central $(3,4)$. In the periphery, endogenous $5-\mathrm{HT}$ is released from mast cells, platelets and endothelial cells in response to tissue injury $(5,6)$.

Administration of exogenous 5-HT may produce hyperpolarization and/or depolarization depending on the population of neurons recorded and the receptor type activated (7). Formalin-induced nociception seems to involve local 5- $\mathrm{HT}$ release (8,9). Peripheral 5- $\mathrm{HT}_{2}, 5-\mathrm{HT}_{3}, 5-\mathrm{HT}_{4}, 5-\mathrm{HT}_{6}$, and $5-\mathrm{HT}_{7}$ receptors are involved in the sensitization of primary afferent fibers activated by formalin injection (10). Among these receptor subtypes, 5- $\mathrm{HT}_{2 \mathrm{~A}}$ receptors have an important role in inflammatory pain $(3,11)$. In an anesthetized animal, afferent nerve activity is scarce and only present if a specific receptor is activated. Therefore, it is reasonable to infer that a surge in neuronal afferent activity after formalin injection, in a nerve ramus that was previously silent, can be due to nociceptive receptor activation.

Sertraline is a highly selective inhibitor of 5-HT reuptake (12). Drugs from its class, the selective serotonin re-uptake inhibitor (SSRI) antidepressants, are also used in the treatment of chronic pain states, either alone or as adjuvants (13). The antidepressant effect occurs after 2-3 weeks of treatment, while the analgesic action is already present after administration of a single dose (14). The analgesic effect of

Correspondence: C.H. Santuzzi, Departamento de Ciências Fisiológicas, CCS, UFES, Av. Marechal Campos, 1468, 29042-751 Vitória, ES, Brasil. E-mail: cintiasantuzzi@yahoo.com.br

Received May 1, 2011. Accepted October 31, 2011. Available online November 18, 2011. Published January 16, 2012. 
SSRIs seems to involve serotonergic mechanisms and the activation of endogenous opioid systems $(15,16)$.

$5-\mathrm{HT}$ is both a central neurotransmitter and a peripheral mediator of inflammation and inflammatory pain $(17,18)$. This bioamine has important effects on the cardiovascular system both peripherally and centrally (19). For instance, central $5-\mathrm{HT}$, acting on its several receptor subtypes, plays a role in the central control of heart rate, blood pressure and respiration (18). Serotonergic neurons in the brainstem project to various sites in the central nervous system and exert powerful neuromodulatory influences on the motor system, such as respiratory control $(20,21)$. However, serotonin receptor activation can produce both excitatory and inhibitory effects on respiratory control, which appears to be related to experimental preparation, developmental stage, animal species, and route of drug administration (22).

Therefore, the objective of the present study was to determine the antihyperalgesic effect of sertraline, indirectly assessed through the changes of sciatic nerve activity, and its influence on the cardiorespiratory parameters in the formalininduced nociception model using anesthetized rats.

\section{Material and Methods}

\section{Animal care and experimental groups}

Male Wistar rats weighing 250-300 g from our breeding stock (Centro de Ciências da Saúde, Universidade Federal do Espírito Santo, UFES) were used. The animals were divided into four groups [saline + saline (Sal + Sal); Sal + formalin (Sal + Form); sertraline + Sal (Sert + Sal), and Sert + Form; $\mathrm{N}=8$ each)]. Animals received sertraline (3 $\mathrm{mg} \cdot \mathrm{kg}^{-1} \cdot \mathrm{day}^{-1}$, ip) or saline $(0.9 \% \mathrm{NaCl}$, ip) for 7 days. The animals of each group were kept in separate cages (8 rats/cage) on a 12-h light/12-h dark cycle at a controlled temperature of $22^{\circ} \mathrm{C}$, under artificial lighting and with food and water ad libitum. The study was approved by the Animal Ethics Committee of the UFES (CEUA No. 017/2009), and the care and use of animals conformed to national and international guidelines.

\section{Surgical procedures and experimental design}

Rats were initially anesthetized with $3 \%$ halothane in an induction chamber and subsequently maintained with urethane $(1.2 \mathrm{~g} / \mathrm{kg}, \mathrm{iv})$. These anesthetics were chosen because they are widely used in experiments that involve nerve recordings and are recommended for their minimal effects on nerve activity. Under halothane anesthesia, the animals were placed in the supine position and a heparinized (1000 U/mL) saline-filled PE-50 catheter was inserted into the left femoral artery and vein. A flexible elastic tube was inserted into the trachea. The rats were then placed in the prone position, and a microscope (M-900, D.F., Brazil) was used for dissecting the right sciatic nerve ( $\mathrm{ScN})$. Subsequent nerve activity was recorded in arbitrary units using silver wire electrodes. The branch of the $\mathrm{ScN}$ that was selected to record afferent electrical activity was sectioned in order to prevent the recording of efferent motor activity. Mineral oil and vaseline were placed on the incision to prevent nerve lesion and to maintain nerve integrity. The parameters measured were ScN activity, mean arterial pressure (MAP), heart rate (HR), respiratory frequency (RF), and serum serotonin level.

\section{Saline or formalin injection in the rat paw}

The formalin administration was performed according to the method of Dubuisson and Dennis (23), whereby $50 \mu \mathrm{L} 5 \%(\mathrm{v} / \mathrm{v})$ formalin or saline was subcutaneously injected into the right paw as an acute pain stimulus. The injection was performed on the eighth day after treatment, $1 \mathrm{~h}$ after the surgical procedures, at the beginning of the experimental protocol.

\section{Sciatic nerve electrical activity and cardiorespiratory parameters}

One hour after the surgical procedures, the extracellular action potentials were recorded with an AC amplifier (NL104, NeuroLog ${ }^{\circledR}$, Digitimer, UK). The signals were filtered (NL-126, NeuroLog ${ }^{\circledR}$ ), connected to an audio amplifier (NL120 , NeuroLog ${ }^{\circledR}$ ) and linked to an oscilloscope (Tektronix 2205 , USA). Subsequently, signals were processed with a spike trigger discriminator (NL-200, NeuroLog $\left.{ }^{\circledR}\right)$ and pulse integrator (NL-601, NeuroLog $\left.{ }^{\circledR}\right)$. The cardiorespiratory parameters (MAP, HR and RF) were recorded by connecting the catheters placed into the left femoral artery and trachea to a Gould polygraph (RS3400). These signals were simultaneously digitalized with the Acknowledge Software for Windows (Biopac ${ }^{\circledR}$ System, USA) for subsequent analysis. Unless otherwise stated, all results are reported as the difference from basal value $(\Delta)$.

\section{Measurement of serum serotonin concentration}

At the end of the experimental protocol (60 min after formalin injection) the animals were decapitated and blood samples were collected for analysis of serum 5-HT and stored at $-80^{\circ} \mathrm{C}$. The concentration of serotonin in stored serum samples was determined with an enzyme-linked immunosorbent assay kit $(\mathrm{GmbH}$, Immunotech/Coulter, Canada) (24).

\section{Drugs}

The following substances were used in the present study: $5 \%$ formalin (formaldehyde; Synth, Brazil) dissolved in distilled water and injected into the hindpaw; halothane, an inhalation anesthetic (2-bromo-2-chloro-1,1,1-trifluoroethane; Cristália, Brazil); urethane, a general anesthetic injected intravenously (Sigma-Aldrich, USA), and sertraline hydrochloride dissolved in distilled water (Sigma-Aldrich).

\section{Statistical analysis \\ Unless otherwise stated, the changes in cardiorespira-}


tory and sciatic nerve activity parameters were compared by two-way ANOVA, followed by the a posteriori Fisher test. The changes in serum 5-HT levels were compared by one-way ANOVA followed by the a posteriori Tukey test. All data are reported as means \pm SEM. Differences were considered to be significant at $\mathrm{P}<0.05$.

\section{Results}

The injection of formalin into the intraplantar region of the right hindpaw (Sal + Form) caused an increase in the afferent activity of the $\mathrm{ScN}$ in the first phase $(\% \Delta \mathrm{ScN}$ in $10 \mathrm{~min}:+28.25 \pm 8.5 \%)$ and in the second phase [starting within $30 \mathrm{~min}(\% \Delta \mathrm{ScN}$ in $30 \mathrm{~min}:+40.6 \pm 11.1 \%, 40 \mathrm{~min}$ : $+50.8 \pm 14.7 \%$, and $50 \mathrm{~min}:+49.3 \pm 14 \%$ )] of the formalin test. However, during the latter phase, pretreatment with sertraline (Sert + Form) significantly depressed the ScN activity $(\% \Delta \mathrm{ScN}$ in $40 \mathrm{~min}:+20.1 \pm 7.2 \%$ and $50 \mathrm{~min}:+19.8$ $\pm 6.9 \%$; Figure $1 \mathrm{~A}$ ).

As shown in Figure 1B, the injection of formalin caused an increase in MAP $(\triangle \mathrm{MAP}$ in the Sal + Form group at 10 $\min : 0.37 \pm 2.2 ; 20 \mathrm{~min}: 0.25 \pm 2.3 ; 30 \mathrm{~min}: 1.37 \pm 3.3 ; 40$ $\min : 1.37 \pm 3 ; 50 \mathrm{~min}: 1.40 \pm 3 \mathrm{mmHg}$ and in the Sert + Form group at $10 \mathrm{~min}:-3.3 \pm 1.7 ; 20 \mathrm{~min}:-3.5 \pm 2.7 ; 30$ min: $-3.3 \pm 2.3$; $40 \mathrm{~min}:-3.2 \pm 2.2 ; 50 \mathrm{~min}:-3.3 \pm 2 \mathrm{mmHg}$ ) compared to the Sal + Sal group ( $\triangle$ MAP in 10 min: $-10.1 \pm$ 1.6; 20 min: $-14.4 \pm 2.8$; 30 min: $-16.7 \pm 3.4$; 40 min: $-19.1 \pm$ 3.9; $50 \mathrm{~min}:-19 \pm 3.9 \mathrm{mmHg}$ ) and Sert + Sal group ( $\triangle$ MAP in $10 \mathrm{~min}:-6.2 \pm 2.5 ; 20 \mathrm{~min}:-13.5 \pm 5.3 ; 30 \mathrm{~min}:-16.5 \pm$ 5.8; $40 \mathrm{~min}:-20.1 \pm 5.6$; $50 \mathrm{~min}:-20.7 \pm 4.3 \mathrm{mmHg}$ ) at all times analyzed.

Formalin injection induced an increase in $\mathrm{HR}(\Delta \mathrm{HR}$ in
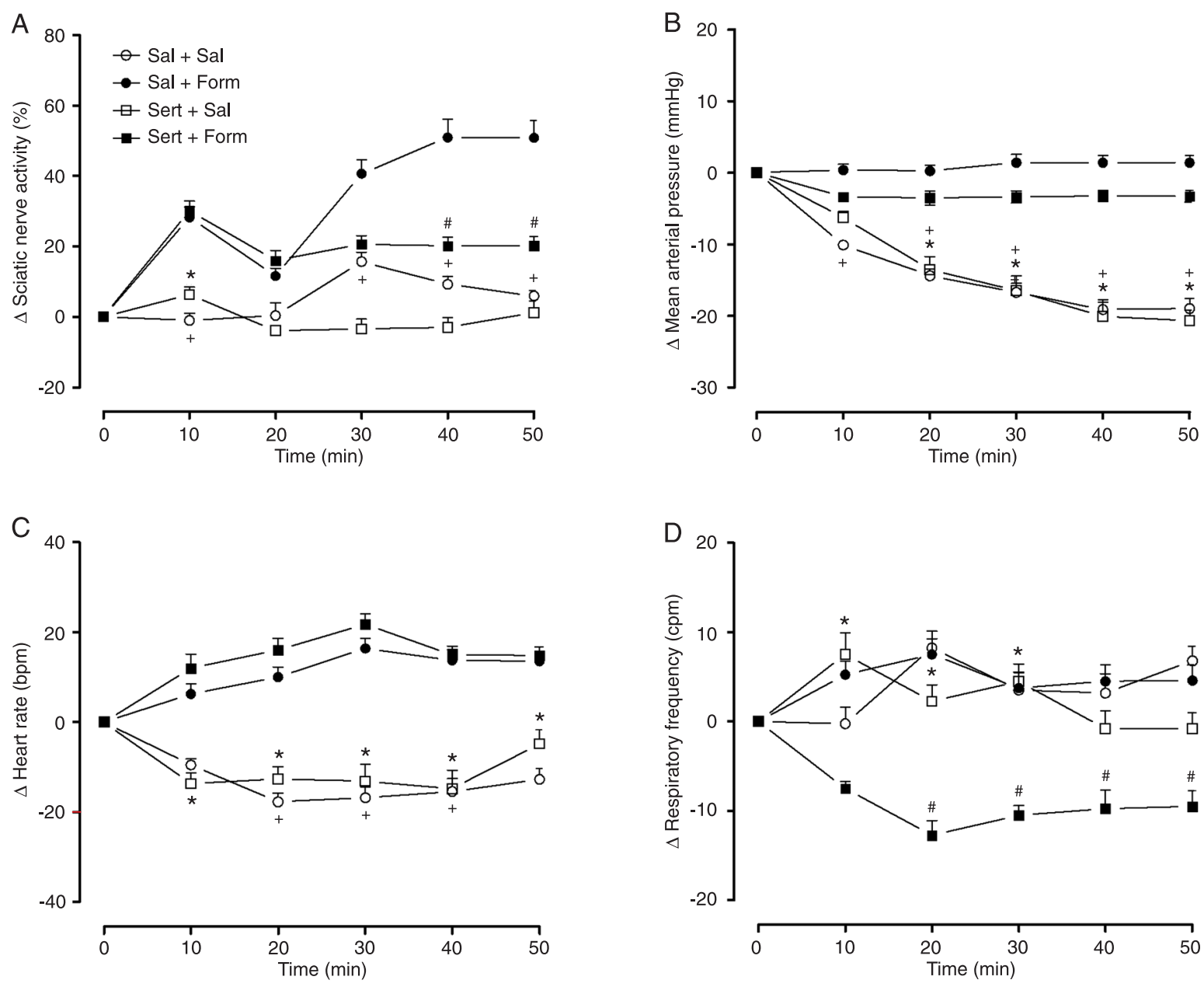

Figure 1. Effects of sertraline administration on $A$, sciatic nerve activity; $B$, mean arterial pressure; $C$, heart rate; $D$, respiratory frequency in an animal model of acute pain produced by the injection of $50 \mu \mathrm{L} \%$ formalin. Data are reported as means $\pm \mathrm{SEM}$ for $\mathrm{N}=8$ rats per group. Sal = saline; Form $=$ formalin; Ser $=$ sertraline. ${ }^{*} \mathrm{P}<0.05$, Sert + Form $v s$ Sert + Sal group; ${ }^{+} \mathrm{P}<0.05$, Sal + Form $v s$ Sal + Sal; $\# \mathrm{P}<0.05$, Sal + Form vs Sert + Form group (analysis of variance (ANOVA) followed by the post hoc Fisher test). 
Sal + Form group in $10 \mathrm{~min}: 6.25 \pm 6.4 ; 20 \mathrm{~min}: 10 \pm 6.4$; 30 min: $16.3 \pm 6.5 ; 40 \mathrm{~min}: 13.7 \pm 6.9 ; 50 \mathrm{~min}: 13 \pm 6.8$ bpm and in Sert + For group in $10 \mathrm{~min}: 12 \pm 8.9 ; 20 \mathrm{~min}$ : $16 \pm 7.2 ; 30 \mathrm{~min}: 21.7 \pm 6.8 ; 40 \mathrm{~min}: 15 \pm 5.4 ; 50 \mathrm{~min}: 15.3$ $\pm 5 \mathrm{bpm})$ compared to the Sal + Sal group ( $\triangle \mathrm{HR}$ in $10 \mathrm{~min}$ : $-9.4 \pm 3.6$; $20 \mathrm{~min}:-17.6 \pm 5.5$; $30 \mathrm{~min}:-16.8 \pm 6.8 ; 40 \mathrm{~min}$ : $-14.4 \pm 8.2 ; 50 \mathrm{~min}:-12.7 \pm 7 \mathrm{bpm})$ and Sert + Sal group ( $\Delta \mathrm{HR}$ in $10 \mathrm{~min}:-13.6 \pm 6.8 ; 20 \mathrm{~min}:-12.6 \pm 8$; $30 \mathrm{~min}:-13.1$ \pm 10.8 ; $40 \mathrm{~min}:-14.8 \pm 11.7 ; 50 \mathrm{~min}:-4.8 \pm 8.9 \mathrm{bpm})$ at all times analyzed (Figure 1C).

Pretreatment with sertraline was able to reduce RF 20 min after formalin injection $(\triangle \mathrm{RF}$ in Sert + Form in $20 \mathrm{~min}$ : $-12.7 \pm 4.7 ; 30 \mathrm{~min}:-10.5 \pm 3.1 ; 40 \mathrm{~min}:-9.7 \pm 5.8 ; 50 \mathrm{~min}$ : $-9.8 \pm 5.7 \mathrm{cpm}$ vs Sal + Form in $20 \mathrm{~min}: 7.5 \pm 5$; $30 \mathrm{~min}$ : $3.7 \pm 5$; $40 \mathrm{~min}: 4.5 \pm 5.1 ; 50 \mathrm{~min}: 4.6 \pm 5 \mathrm{cpm}$ ) (Figure 1D). On the other hand, sertraline was not able to decrease RF without formalin $(\triangle \mathrm{RF}$ in Sert + Sal in $10 \mathrm{~min}: 7.5 \pm 6.8 ; 20$ $\min : 2.25 \pm 5.3 ; 30 \mathrm{~min}: 4.5 \pm 5.5 ; 40 \mathrm{~min}:-0.8 \pm 5.7 ; 50$ min: $-0.8 \pm 5 \mathrm{cpm})$.

Formalin injection promoted an increase in the level of serum 5-HT in the Sal + Form group (1162 $\pm 124.6 \mathrm{ng} /$ $\mathrm{mL}$ ) and pretreatment with sertraline was able to normalize the serum levels of 5-HT (Sert + Form = 634.2 \pm 69 ; Sert + Sal $=612.4 \pm 47.8$ and Sal + Sal $=683.3 \pm 70.6 \mathrm{ng} /$ $\mathrm{mL}$; Figure 2).

\section{Discussion}

The present study showed that sertraline inhibits a classical experimental model of pain, the formalin-induced nociception. Sertraline was able to attenuate the increase in the afferent activity of the $\mathrm{ScN}$ after a painful stimulus. This effect was accompanied by a decrease in RF and a decrease in serum 5-HT concentration. In addition, formalin administration caused an increase in MAP and tachycardia.

Formalin is an agent used to induce hyperalgesia and inflammation in rat paws, and this model has been considered to be a suitable model for acute clinical pain (25). McNamara et al. (26) showed that formalin activates primary afferent sensory neurons through a specific and direct action on TRPA1, a member of the transient receptor potential family of cation channels that is highly expressed by a subset of $\mathrm{C}$-fiber nociceptors. The nociceptive response to formalin occurs in a biphasic pattern: there is an initial acute period (phase 1, duration of $7 \pm 10 \mathrm{~min}$ ) and, after a short period of remission, phase 2 begins, consisting of a longer period $(1 \mathrm{~h})$ of sustained activity $(27,28)$. Phase 1 is thought to be produced by the acute activation of primary afferent fibers by formalin injection (neurogenic pain), whereas phase 2 has been associated with the release of local endogenous mediators responsible for sensitization of primary and spinal sensory neurons and subsequent activation of the nociceptors (27), including 5-HT, histamine, bradykinin, and prostaglandins, which accounts for the

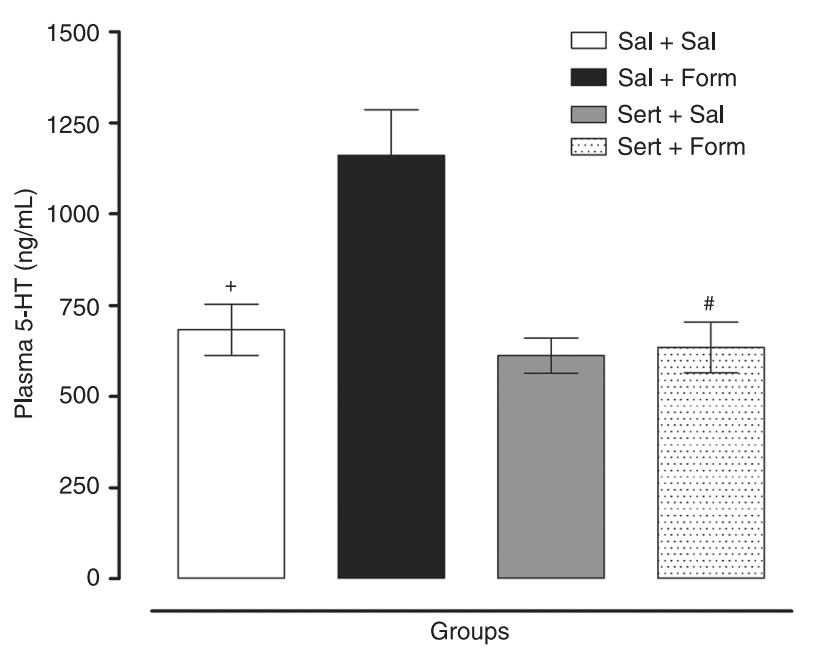

Figure 2. Plasma levels of serotonin (5-HT) 50 min after formalin or saline injection into the rat paw. Data are reported as means \pm SEM for $\mathrm{N}=8$ rats per group. Sal = saline; Form = formalin; Ser $=$ sertraline. ${ }^{+} \mathrm{P}<0.05$, Sal + Form vs Sal + Sal; ${ }^{\# P}<0.01$, Sal + Form vs Sert + Form group (one-way ANOVA).

sensitization of primary afferent fibers (inflammatory pain) (29-31). Our results are based on an indirect marker of nociceptive activation, i.e., afferent $\mathrm{ScN}$ activity. Formalin injection induced an increase in ScN activity in phase 1 (10 min) and phase 2 (from 30 min on), with a short period of remission (20 min). Pretreatment with sertraline was able to decrease $\mathrm{ScN}$ activity in phase 2 .

Nakajima et al. (9) demonstrated that formalin injection induced a dose-dependent $5-\mathrm{HT}$ release during phase $2 \mathrm{~A}$ (12-30 min after formalin injection) of the formalin test. Furthermore, recent studies have suggested that formalin would induce peripheral 5-HT release, which in turn would activate 5-HT receptors in primary afferent fibers (8). Our data agree with these observations and show that formalin injection increases serum serotonin concentration, which may contribute to the increase in nerve activity. In order to confirm or not this suggestion, studies evaluating the effect of 5-HT receptor antagonists on the increased ScN activity caused by formalin are now in progress. Our data also demonstrated that sertraline was able to change the serum levels of $5-\mathrm{HT}$ to baseline values, possibly contributing to the inhibitory effect of this drug on ScN activity.

The analgesic properties of SSRIs have only been partially studied. Abdel-Salam et al. (12) demonstrated that sertraline displayed antinociceptive effects in the electrical stimulation of the tail flick test, probably by potentiating supraspinal 5-HT-mediated processes and interactions with biogenic amine, opioid and/or adenosine systems. Corroborating these findings, Wang et al. (32) demonstrated that sertraline and paroxetine block $\mathrm{Na}^{+}$currents and this blocking action on the open neuronal $\mathrm{Na}^{+}$channel could work 
cooperatively with other pharmacological targets of these SSRI antidepressants on the central and peripheral pain pathways. Furthermore, Otsuka et al. (33) demonstrated that sertraline $(20 \mathrm{mg} / \mathrm{kg})$ produced a significant reduction in the time the animals spent licking the injected paw in the formalin test. Our findings showed that sertraline, under the present experimental conditions and in the dose and treatment regimen applied ( $3 \mathrm{mg} \cdot \mathrm{kg}^{-1} \cdot \mathrm{day}^{-1}$ for 7 days), was also able to reduce formalin-induced nociception.

We also examined the effects of sertraline on the cardiorespiratory system both independently and in association with a nociceptive stimulus. Thus, we observed an increase in MAP and HR of formalin trial groups not previously treated with sertraline. It has been well established that nociception modulates HR and MAP, validating the use of these parameters as indicators of pain in animal models $(34,35)$. Sertraline also reduced RF after the nociceptive stimulus. The idea that serotonergic neurons participate in the regulation of respiration is supported by the presence of serotonergic nerve terminals and serotonergic receptors in respiratory nuclei such as the nucleus tractus solitarii, the

\section{References}

1. Sufka KJ, Schomburg FM, Giordano J. Receptor mediation of 5-HT-induced inflammation and nociception in rats. Pharmacol Biochem Behav 1992; 41: 53-56.

2. Oliveira MC, Pelegrini-da-Silva A, Parada CA, Tambeli $\mathrm{CH}$. 5-HT acts on nociceptive primary afferents through an indirect mechanism to induce hyperalgesia in the subcutaneous tissue. Neuroscience 2007; 145: 708-714.

3. Godinez-Chaparro B, Barragan-Iglesias P, CastanedaCorral G, Rocha-Gonzalez HI, Granados-Soto V. Role of peripheral $5-\mathrm{HT}(4), 5-\mathrm{HT}(6)$, and $5-\mathrm{HT}(7)$ receptors in development and maintenance of secondary mechanical allodynia and hyperalgesia. Pain 2011; 152: 687-697.

4. Lin SY, Chang WJ, Lin CS, Huang CY, Wang HF, Sun WH. Serotonin receptor 5 -HT2B mediates serotonin-induced mechanical hyperalgesia. J Neurosci 2011; 31: 1410-1418.

5. Millan MJ. The induction of pain: an integrative review. Prog Neurobiol 1999; 57: 1-164.

6. Sommer C. Serotonin in pain and analgesia: actions in the periphery. Mol Neurobiol 2004; 30: 117-125.

7. Granados-Soto V, Arguelles CF, Rocha-Gonzalez HI, Godinez-Chaparro B, Flores-Murrieta FJ, Villalon CM. The role of peripheral 5-HT1A, 5-HT1B, 5-HT1D, 5-HT1E and 5-HT1F serotonergic receptors in the reduction of nociception in rats. Neuroscience 2010; 165: 561-568.

8. Castaneda-Corral G, Rocha-Gonzalez HI, Araiza-Saldana Cl, Ambriz-Tututi M, Vidal-Cantu GC, Granados-Soto V. Role of peripheral and spinal 5-HT6 receptors according to the rat formalin test. Neuroscience 2009; 162: 444-452.

9. Nakajima K, Obata H, Ito N, Goto F, Saito S. The nociceptive mechanism of 5-hydroxytryptamine released into the peripheral tissue in acute inflammatory pain in rats. Eur $\mathrm{J}$ Pain 2009; 13: 441-447.

10. Tambeli $\mathrm{CH}$, Oliveira MC, Clemente JT, Pelegrini-da- hypoglossal nucleus and the preBötzinger complex $(36,37)$. Annerbrink et al. (38) showed that acute administration of an SSRI (fluoxetine or paroxetine) caused a significant reduction in $\mathrm{RF}$, while subchronic treatment for 23 days increased it. Confirming these findings, the present study showed that a 7-day treatment with sertraline was effective in reducing $\mathrm{RF}$.

The results presented here suggest that treatment with sertraline inhibits the afferent activity of the $\mathrm{ScN}$ caused by formalin injection into rats. In addition, we demonstrated that sertraline was able to decrease the MAP, HR and RF responses to nociceptive receptor activation. Moreover, all of these changes probably involve peripheral serotonergic mechanisms. Further understanding of this process may help the development of peripherally acting analgesic drugs.

\section{Acknowledgments}

Research partially supported by a CNPq grant to C.H. Santuzzi, and a CAPES grant to R.V. Tiradentes.

Silva A, Parada CA. A novel mechanism involved in 5-hydroxytryptamine-induced nociception: the indirect activation of primary afferents. Neuroscience 2006; 141: 1517-1524.

11. Sasaki M, Obata H, Kawahara K, Saito S, Goto F. Peripheral 5-HT2A receptor antagonism attenuates primary thermal hyperalgesia and secondary mechanical allodynia after thermal injury in rats. Pain 2006; 122: 130-136.

12. Abdel-Salam OM, Nofal SM, El-Shenawy SM. Evaluation of the anti-inflammatory and anti-nociceptive effects of different antidepressants in the rat. Pharmacol Res 2003; 48: 157165.

13. Fishbain DA, Cutler R, Rosomoff HL, Rosomoff RS. Evidence-based data from animal and human experimental studies on pain relief with antidepressants: a structured review. Pain Med 2000; 1: 310-316.

14. Korzeniewska-Rybicka I, Plaznik A. Analgesic effect of antidepressant drugs. Pharmacol Biochem Behav 1998; 59: 331-338.

15. Bourin M, Chue P, Guillon Y. Paroxetine: a review. CNS Drug Rev 2001; 7: 25-47.

16. Banks ML, Rice KC, Negus SS. Antinociceptive interactions between Mu-opioid receptor agonists and the serotonin uptake inhibitor clomipramine in rhesus monkeys: role of Mu agonist efficacy. J Pharmacol Exp Ther 2010; 335: 497505.

17. Olsson M, Annerbrink K, Bengtsson F, Hedner J, Eriksson E. Paroxetine influences respiration in rats: implications for the treatment of panic disorder. Eur Neuropsychopharmacol 2004; 14: 29-37.

18. Ramage AG, Villalon CM. 5-hydroxytryptamine and cardiovascular regulation. Trends Pharmacol Sci 2008; 29: 472481.

19. Ramage AG. Central cardiovascular regulation and 5-hy- 
droxytryptamine receptors. Brain Res Bull 2001; 56: 425439.

20. Hodges MR, Richerson GB. Contributions of 5-HT neurons to respiratory control: neuromodulatory and trophic effects. Respir Physiol Neurobiol 2008; 164: 222-232.

21. Hodges MR, Richerson GB. Interaction between defects in ventilatory and thermoregulatory control in mice lacking $5-\mathrm{HT}$ neurons. Respir Physiol Neurobiol 2008; 164: 350-357.

22. Bartman ME, Wilkerson JE, Johnson SM. 5-HT3 receptordependent modulation of respiratory burst frequency, regularity, and episodicity in isolated adult turtle brainstems. Respir Physiol Neurobiol 2010; 172: 42-52.

23. Dubuisson D, Dennis SG. The formalin test: a quantitative study of the analgesic effects of morphine, meperidine, and brain stem stimulation in rats and cats. Pain 1977; 4: 161174.

24. Hara K, Hirowatari Y, Yoshika M, Komiyama Y, Tsuka Y, Takahashi $\mathrm{H}$. The ratio of plasma to whole-blood serotonin may be a novel marker of atherosclerotic cardiovascular disease. J Lab Clin Med 2004; 144: 31-37.

25. Kim JH, Gwak YS, Lee I, Sohn IC, Kim MS, Choi DO, et al. Antinociceptive effects of heterotopic electroacupuncture in formalin-induced pain. Am J Chin Med 2006; 34: 565-574.

26. McNamara CR, Mandel-Brehm J, Bautista DM, Siemens J, Deranian KL, Zhao M, et al. TRPA1 mediates formalininduced pain. Proc Natl Acad Sci U S A 2007; 104: 1352513530.

27. Parada CA, Tambeli $\mathrm{CH}$, Cunha FQ, Ferreira SH. The major role of peripheral release of histamine and 5-hydroxytryptamine in formalin-induced nociception. Neuroscience 2001; 102: 937-944.

28. Dang $Y H$, Xing B, Zhao Y, Zhao XJ, Huo FQ, Tang JS, et al. The role of dopamine receptors in ventrolateral orbital cortex-evoked antinociception in a rat formalin test model. Eur J Pharmacol 2011; 657: 97-103.

29. Doak GJ, Sawynok J. Formalin-induced nociceptive be- havior and edema: involvement of multiple peripheral 5-hydroxytryptamine receptor subtypes. Neuroscience 1997; 80: 939-949.

30. Carvalho AA, Galdino PM, Nascimento MV, Kato MJ, Valadares MC, Cunha LC, et al. Antinociceptive and antiinflammatory activities of grandisin extracted from Virola surinamensis. Phytother Res 2010; 24: 113-118.

31. Lee HG, Kim WM, Park CH, Yoon MH. Roles of adenosine and serotonin receptors on the antinociception of sildenafil in the spinal cord of rats. Yonsei Med J 2010; 51: 960-964.

32. Wang GK, Mitchell J, Wang SY. Block of persistent late $\mathrm{Na}^{+}$currents by antidepressant sertraline and paroxetine. $J$ Membr Biol 2008; 222: 79-90.

33. Otsuka N, Kiuchi Y, Yokogawa F, Masuda Y, Oguchi K, Hosoyamada A. Antinociceptive efficacy of antidepressants: assessment of five antidepressants and four monoamine receptors in rats. $J$ Anesth 2001; 15: 154-158.

34. Rigaud M, Gemes G, Abram SE, Dean C, Hopp FA, Stucky $\mathrm{CL}$, et al. Pain tests provoke modality-specific cardiovascular responses in awake, unrestrained rats. Pain 2011; 152: 274-284.

35. Culman J, Ritter S, Ohlendorf C, Haass M, Maser-Gluth C, Spitznagel $\mathrm{H}$, et al. A new formalin test allowing simultaneous evaluation of cardiovascular and nociceptive responses. Can J Physiol Pharmacol 1997; 75: 1203-1211.

36. Feldman JL, Mitchell GS, Nattie EE. Breathing: rhythmicity, plasticity, chemosensitivity. Annu Rev Neurosci 2003; 26: 239-266.

37. Richerson GB, Wang W, Hodges MR, Dohle Cl, DiezSampedro A. Homing in on the specific phenotype(s) of central respiratory chemoreceptors. Exp Physiol 2005; 90: 259-266.

38. Annerbrink K, Olsson M, Hedner J, Eriksson E. Acute and chronic treatment with serotonin reuptake inhibitors exert opposite effects on respiration in rats: possible implications for panic disorder. J Psychopharmacol 2010; 24: 1793-1801. 